\title{
SCIDoc

\section{p53 Expression in Pterygium Amongst Natives of High Versus Low Altitude}

Research Article

\author{
Anthwal $\mathrm{D}^{1^{*}}$, Gupta $\mathrm{M}^{2}$, Dasgupta $\mathrm{S}^{3}$, Tyagi $\mathrm{R}^{4}$
}

${ }^{1}$ Junior Resident, Department of Ophthalmology, Shri Guru Ram Rai Institute of Medical \& Health Sciences, Patel Nagar, Dehradun, Uttarakhand, India.

${ }^{2}$ Professor and Head, Department of Ophthalmology, Shri Guru Ram Rai Institute of Medical \& Health Sciences, Patel Nagar, Dehradun, Uttarakhand, India.

${ }^{3}$ Associate Professor, Department of Ophthalmology, Shri Guru Ram Rai Institute of Medical \& Health Sciences, Patel Nagar, Dehradun, Uttarakhand, India.

${ }^{4}$ Assistant Professor, Department of Ophthalmology, Shri Guru Ram Rai Institute of Medical \& Health Sciences, Patel Nagar, Dehradun, Uttarakhand, India.

\section{Abstract}

Purpose: To evaluate and compare the p53 gene expression in pterygia excised from natives of high and low altitudes. Methods: This prospective randomised interventional study, including 40 eyes ( 40 pterygia) of 40 patients, was conducted at our tertiary care institute for a period of 21 months. Patients admitted indoors were randomly selected for the study. Pterygium excision with conjunctival autografting was the standard procedure done. Pterygia and controls (normal conjunctiva) excised from both high $(\geq 1500 \mathrm{~m})$ and low altitude $(<1500 \mathrm{~m})$ groups were analyzed immunohistochemically for p53 gene expression.

Results: Overall, 29 (72.5\%) pterygium specimens stained positive for p53 gene expression (p-value $=0.0001) .15(75 \%)$ pterygia from high altitude $(\mathrm{p}$-value $=0.0002)$ and $14(70 \%)$ pterygia from low altitude group $(\mathrm{p}$-value $=0.0003)$ stained $\mathrm{p} 53$ positive. Mean mutant p53 immunoreactivity was $31.03 \pm 18.19 \%$. However, the difference in incidence of p53 positivity $(\mathrm{p}$-value $=1)$ or mean $\mathrm{p} 53$ immunoreactivity $(\mathrm{p}$-value $=0.53)$ between the two study groups was not significant. All normal conjunctiva specimens stained p53 negative.

Conclusions: Notwithstanding the difference in ultraviolet irradiation, the altitudinal variation in p53 gene expression in pterygium was found insignificant in our study. However, significantly high rate of mutant p 53 positivity suggests pterygium to be a disorder of cell proliferation. Despite remaining unaffected by altitude, such alarmingly high incidence of p53 positivity warrants further randomised multicentric studies to rule out pterygium premalignancy and to investigate other possible mechanism(s) of p53 mutation in pterygium, besides those mediated by ultraviolet radiation.

Keywords: Altitude; p53 Expression; Premalignant; Pterygium, UV Radiation.

\section{Introduction}

Pterygium is a fibrovascular neoformation of the ocular surface, traditionally described as a wing shaped ingrowth of degenerative bulbar conjunctival tissue, over the limbus, onto the cornea [1]. It is composed of epithelium and highly vascular subepithelial loose connective tissue. Interestingly, pterygium has a predilection for the nasal limbus and affects only humans, possibly owing to our unique ocular morphology. It not only affects the cosmetic outlook, but also is a potentially blinding disease in the advanced stage due to invasion of the visual axis [2]. In severe cases, visual loss may arise from irregular corneal astigmatism, corneal stromal scarring and obscuration of the visual axis, while ocular irritation often occurs as a result of ocular surface inflammation at the site of the pterygium [3, 4]. Although, a relatively benign lesion, pterygium can be locally invasive exhibiting tumour like characteristics, varying from mild dysplasia to carcinoma in situ [5].

Despite its original description dating back to 1000 B.C., pterygium still remains an ophthalmic enigma in terms of its pathogen-

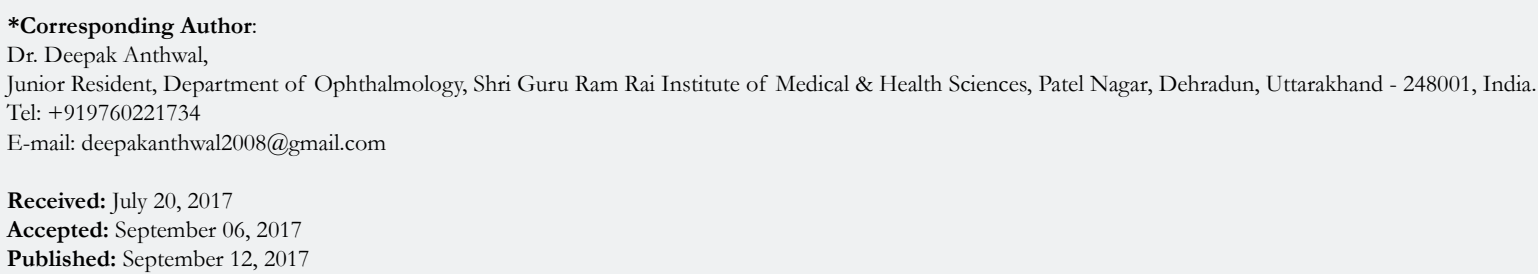

Copyright: Anthwal $\mathbf{D}^{\circ}$ 2017. This is an open-access article distributed under the terms of the Creative Commons Attribution License, which permits unrestricted use, distribution and reproduction in any medium, provided the original author and source are credited. 
esis [6]. Pterygium was originally considered as 'ophthalmo-heliosis', i.e., a condition related to increased exposure to sunshine [7, 8]. Ever since, several factors including male sex, outdoor occupation and advanced age have been associated with the increased incidence of pterygium [9]. Exposure to sunlight, particularly reflected ultraviolet (UV) component of sunlight has been proposed to be the primary causative agent, involving genetic mutations in pterygium cells, leading to subsequent pterygium development [10-12].

The gene p53 (wild type), located at chromosome 17p13, is a tumour suppressor gene that controls the cell cycle [13, 14]. It is involved in DNA repair and synthesis, cell differentiation and apoptosis. Mutations in the p53 gene (mutant type) are said to be the most common genetic marker of human neoplastic growth. The p53 gene product, the p53 protein, is a nuclear phosphoprotein which binds to the DNA and can be identified by immunohistochemical (IHC) staining, using a specific monoclonal antibody [15]. Owing to a short half-life, the $\mathrm{p} 53$ protein concentration in normal cells is very low, so the cells stain negative $[16,17]$. However, in most neoplastic cells its concentration is higher and hence IHC staining for the $\mathrm{p} 53$ protein becomes positive [18-20]. Recent use of various molecular genetic analysis techniques have led to several theories of pterygium pathogenesis, making way for new therapeutic possibilities [21-26]. Although, there is no consensus on the pathogenesis of pterygium, recent reports suggest that it is a proliferative rather than a degenerative disorder, strongly correlated with exposure to ultraviolet light $[27,28]$.

Some studies investigating p53 gene expression in pterygium have reported incidence of pterygium $\mathrm{p} 53$ positivity ranging between $7.9 \%$ and $100 \%$ [29-36]. A few studies have pointed towards a higher prevalence of pterygium in the natives of high altitude [3740]. However, to the best of our knowledge, a study investigating the altitudinal variation in $\mathrm{p} 53$ gene expression in pterygium has not been reported yet. Such a study could clarify whether or not altitude has any role in the pathogenesis or worsening of pterygium. India, one of the countries lying in the pterygium belt (i.e. $40^{\circ}$ north and south of the equator), has areas of relatively high pterygium prevalence [41-43]. Dehradun $\left(30^{\circ} 19^{\prime} \mathrm{N}\right.$ latitude, altitude $640 \mathrm{~m}$ ), being well connected to the hills of Uttarakhand, Himachal Pradesh and plains of Western Uttar Pradesh, is a place well suited to conduct a study of this type. This study was conducted with the aim to evaluate and compare the p53 gene expression in pterygium amongst the natives of high and low altitudes.

\section{Materials and Methods}

This study was a prospective randomised interventional study conducted at our tertiary care referral centre in Dehradun, for a period of 21 months (from November 2014 to August 2016), after approval from the Institutional Research and Ethics Committee. It was in accordance to the tenets of Declaration of Helsinki. A total of 60 eyes ( 60 patients) were analyzed during this study. Out of these, 20 eyes (20 pterygia) were excluded on the grounds of missing epithelium or insufficiency of specimen for IHC analysis. Eventually, a total of 40 eyes (40 pterygia and 10 normal conjunctival samples) of pterygium patients, aged between 18 to 75 years, admitted in the inpatient department of ophthalmology were included in this study, after taking prior written informed consent. Patients with any ocular infection, recurrent pterygium, pseudo-pterygium, benign or malignant tumour of eye, ocular trauma or burns and any previous ocular or adnexal surgery were excluded from the study.

The patients admitted indoors for surgical excision were randomly selected for the study following a thorough clinical evaluation, including a detailed history and examination. Ocular examination included best corrected visual acuity, intra-ocular pressure measurement, ocular movements, slit-lamp biomicroscopy (Zeiss SL $120, \mathrm{USA})$ and fundus examination. Vitals were recorded and routine laboratory investigations, including complete blood counts, random blood sugar, bleeding time, clotting time and activated partial thromboplastin time were done for each patient. The patients born and living at an altitude of $1500 \mathrm{~m}$ or higher were considered as natives of high altitude, whereas, those born and living at altitudes lower than $1500 \mathrm{~m}$ were considered as inhabitants of low altitude [44]. The native altitude data for each patient was calculated using Bhuvan, a Geo-platform software by Indian Space Research Organisation (ISRO). The annual UV index data (from January 2015 to December 2015) for the native place of each patient was also recorded, sourced from World Weather Online, as it was not available with the State Meteorological Department.

At diagnosis, the grading of pterygium was done, based upon its size [45]. Pterygium extending less than $2 \mathrm{~mm}$ onto the cornea was considered as grade I, that extending up to $4 \mathrm{~mm}$ as grade II, while the one extending more than $4 \mathrm{~mm}$ onto the cornea and involving the visual axis was regarded as grade III. Henceforth, the patients were posted for surgery. Pterygium excision with free conjunctival autografting was the standard surgical procedure. The tissue specimens surgically excised from patients' eyes were categorized into three study groups, viz.; group A, B and C. Group A included 20 pterygia excised from patients of high altitude, while Group B included 20 pterygia excised from patients of low altitude. Group C consisted of 10 normal conjunctival samples (5 each from both the groups, A and B), surgically excised from the supero-temporal limbus of the same eye undergoing pterygium surgery, serving as the control.

\section{Surgical Technique}

Part preparation and draping was done under strict aseptic measures. Castroviejo wire speculum was used to retract the eyelids. A small radial incision was made at limbal conjunctiva adjacent to the neck of the pterygium using crescent keratome and Lim's forceps. Dissection of the head from body was done followed by its dissection from corneal surface using traction and blunt dissection. Fibrovascular body of pterygium was then dissected neatly from the adjoining conjunctiva down to bare sclera, removing any loose Tenon's layer but leaving the episcleral vessels intact. Size of the graft required was estimated using Castroviejo calipers. The limbal-conjunctival autograft was taken from the supero-temporal quadrant and placed over the scleral bed using non toothed forceps and either sutured or left in place for 10 minutes to allow firm adherence of the graft securing it in situ ("sutureless technique"). Operated eye was then patched tightly after instilling topical moxifloxacin $(0.5 \%)$. Postoperatively, topical moxifloxacin $(0.5 \%)$ and difluprednate $(0.05 \%)$ were given 4 times a day and tapered after 2 weeks. After pterygium excision, the excised tissue was stored and transported in 10\% formalin for immunohistochemical examination of p53 (using DO-7 antibody, which can detect mutant p53 under non-denaturing conditions). 


\section{Immunohistochemistry}

Specimens were received in 10\% formalin and grossing was done as per the protocol of histopathology laboratory. All the formalin fixed tissues were processed in automatic tissue processor (Shandon Citadel 2000, UK). Paraffin embedded blocks were made from the processed tissue using Embedding station (Leica EG1150 H+C, Germany). Sections of 2-4 microns were made using Microtome (Shandon Finesse 325, UK), taken on Poly-L lysine coated slides and subjected to IHC using primary p53 antibodies (DO-7, 1/50 Dako, Carpinteria, CA, USA). Sections were incubated with the secondary biotinylated antibody and avidin-biotin peroxidise complexes for 30 minutes. Reaction products were revealed with diaminobenzidine as the chromogen and sections were counterstained with Harris's hematoxylin to enhance nuclear detection. Finally, the slides were mounted with DPX mountant and then microscopic examination was done under 40X power (Nikon Eclipse E200, China). Sections of p53 positive colon carcinoma tissue were used as positive control, whereas duplicate sections having primary antibody substituted with phosphate buffer saline were used as negative control. Nuclear positivity of p53 was seen as dark brown colour over bluish background.

For microscopic examination, each slide was seen under low power and the entire section was screened to find the region with maximum number of $\mathrm{p} 53$ positive cells. Percentage of cells that were p53 positive was calculated by counting at least 1000 cells. A specimen with less than 5\% p53 positive cells was considered as 553 negative. The report for each specimen, confirmed by an expert consultant histopathologist, was noted on the patient pro-forma.

\section{Statistical Analysis}

The statistical analysis was done using SPSS (Statistical Package for Social Sciences) for Windows 18.0 software. The p53 indices were analyzed as categorical variables using Fisher's exact test. Level of significance $(\alpha)$ was set at $5 \%$. Hence, a p-value $<0.05$ was accepted as statistically significant.

\section{Results}

Out of the total 40 patients under study, 14 (35\%) patients were males and $26(65 \%)$ of them were females (Table 1$)$. The incidence of pterygium was significantly higher in females compared to males overall $(\mathrm{p}$-value $=0.007)$ and in group $\mathrm{A}(\mathrm{p}$-value $=$ $0.001)$, but marginally higher in group $B(p$-value $=0.52)$. There was no significant difference in gender distribution between group A and group B ( $\mathrm{p}$-value $=0.32)$, and between all cases and controls $(\mathrm{p}$-value $=1)$.

The overall mean age of all pterygium patients was $42.70 \pm 16.38$ years (range $=18-75$ years; standard deviation $\{S D\}=16.38)$. In group $A$, it was $49.45 \pm 16.43$ years, in group $B$ it was $35.95 \pm$ 13.59 years, whereas, in group $C$ the mean age was $39.50 \pm 8.22$ years (Table 1). There was no significant difference in mean ages between group A and group B ( $\mathrm{p}$-value $=0.99)$, and between all cases and controls $(\mathrm{p}$-value $=0.80)$.

The difference between mean native altitude of group A (1768.60 $\pm 211.20 \mathrm{~m})$ and group $B(384.85 \pm 101.16 \mathrm{~m})$ patients was statistically significant $(\mathrm{p}$-value $=0.0001)$. The difference in annual mean UV index for group A $(5.44 \pm 0.18)$ and group B (6.32 \pm $0.45)$ was statistically significant $(\mathrm{p}$-value $=0.0001)$ as well $($ Table 1).

All 40 cases were primary nasal pterygium, out of which $5(12.5 \%)$ were classified as grade I, 28 (70\%) were grade II and 7 (17.5\%) were classified as grade III pterygium (Table 2). Grade I pterygium was seen only in group $\mathrm{B}$ and not in group $\mathrm{A}$ ( $\mathrm{p}$-value $=$ $0.01)$. The incidence of grade II ( $\mathrm{p}$-value $=0.49)$ and grade III pterygium $(\mathrm{p}$-value $=0.21)$ was insignificantly higher in group $\mathrm{A}$ compared to group B.

On IHC, abnormal or mutant p53 positive cells were seen in the pterygium epithelium, predominantly in the basal layers (Figure 1). Overall, $29(72.5 \%)$ pterygia stained positive for abnormal p53 expression while $11(27.5 \%)$ pterygia stained negative for the

Table 1. Demographic Profile of Patients.

\begin{tabular}{|c|c|c|c|c|}
\hline Patient Data & $\begin{array}{c}\text { Group A } \\
\text { (High Altitude) }\end{array}$ & $\begin{array}{c}\text { Group B } \\
\text { (Low Altitude) }\end{array}$ & $\begin{array}{c}\text { Group C } \\
\text { (Control) }\end{array}$ & Overall \\
\hline Total Number & 20 & 20 & 10 & 40 \\
\hline Male (\%) & $5(25)$ & $9(45)$ & $4(40)$ & $14(35)$ \\
\hline Female (\%) & $15(75)$ & $11(55)$ & $6(60)$ & $26(65)$ \\
p-value & 0.001 & 0.52 & 0.38 & 0.007 \\
\hline Mean Age & 49.45 & 35.95 & 39.50 & 42.70 \\
SD & 16.43 & 13.59 & 8.22 & 16.38 \\
Range & $23-75$ & $18-70$ & $30-50$ & $18-75$ \\
\cline { 1 - 3 } Mean Altitude & 1768.60 & 384.85 & & \\
SD & 211.20 & 101.16 & & \\
\cline { 1 - 3 } UV index & 5.44 & 6.32 & & \\
SD & 0.18 & 0.45 & & \\
\cline { 1 - 3 } & & \multicolumn{3}{|l}{}
\end{tabular}

Mean age and range depicted above is in years. SD stands for the standard deviation. Mean altitude represents the mean of native altitude data of all patients from the respective group and it is measured in metres. UV index represents the mean of native annual ultraviolet index data of all patients from each group. 
Table 2. Incidence of Different Grades of Pterygium.

\begin{tabular}{|c|c|c|c|c|}
\hline $\begin{array}{c}\text { Pterygium } \\
\text { Grade }\end{array}$ & $\begin{array}{c}\text { Group A } \\
\text { (High Altitude) }\end{array}$ & $\begin{array}{c}\text { Group B } \\
\text { (Low Altitude) }\end{array}$ & p-value & Overall \\
\hline Grade I (\%) & $0(0)$ & $5(25)$ & 0.01 & $5(12.5)$ \\
\hline Grade II (\%) & $15(75)$ & $13(65)$ & 0.49 & $28(70)$ \\
\hline Grade III (\%) & $5(25)$ & $2(10)$ & 0.21 & $7(17.5)$ \\
\hline
\end{tabular}

Pterygium grades are based upon the visible size of pterygium mass. Grade I extending up to $2 \mathrm{~mm}$, grade II from 2 to $4 \mathrm{~mm}$, and grade III extending beyond $4 \mathrm{~mm}$ over the cornea [45]. Figures in parenthesis represent the percentage.

Figure 1. Immunohistochemical Staining with DO-7 showing a section of p53 negative (cells with bluish nuclei) pterygium specimen (on the left) at 40X; and a section of p53 positive (cells with brown nuclei) pterygium specimen (on the right) at $40 \mathrm{X}$.
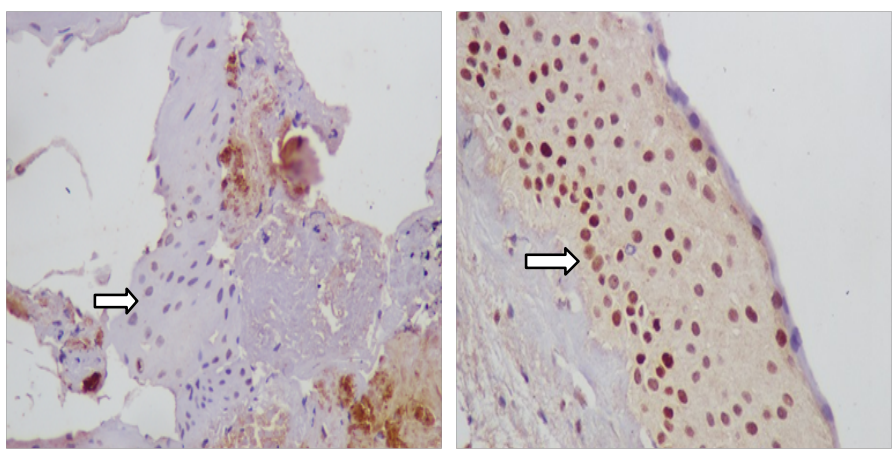

same (Fisher's two tailed p-value $=0.0001)$. In group A, $15(75 \%)$ pterygia stained positive for mutant p53, while $5(25 \%)$ stained negative $(\mathrm{p}$-value $=0.0002)$. In group B, $14(70 \%)$ pterygia were positive for abnormal p53 expression, whereas $6(30 \%)$ pterygia were tested negative for it ( $\mathrm{p}$-value $=0.0003)$. All the controls stained negative for p53 (mutant) expression (Table 3). Although, the p53 gene expression in pterygia was marginally higher in group A compared to group B, but it was statistically insignificant $(\mathrm{p}$-value $=1.0)$.

Quantitative analysis of p53 gene immunoreactivity (positivity) was done for each pterygium specimen by IHC (Table 3). The overall mean p53 (mutant) positivity among all pterygia was 31.03 $\pm 18.19 \%$ ( $\mathrm{SD}=18.19)$. In group $A$, the mean $\mathrm{p} 53$ positivity was $31 \pm 18.34 \%$, while in group B it was $31.07 \pm 18.72 \%$. There was no significant difference in the mean p53 immunoreactivity between group A and group B ( $\mathrm{p}$-value $=0.53)$.

\section{Discussion}

In this study we found that the incidence of pterygium, especially in natives of high altitude (hilly regions), was higher in females as compared to males. The longer duration of daytime outdoor work in females than males in these hilly regions might probably explain the higher incidence of pterygium in females. Similar findings have been reported in the past [37, 46, 47]. In contrast, some studies have claimed a higher incidence in males [11, 48-50]. The mean age of the pterygium patients in our study was over forty years which conforms to the findings reported by previous studies [48-51]. No significant difference was found in the gender distribution or mean age between the two study groups. All the patients included in this study were found to have primary nasal pterygium. Majority of the pterygia were grade II and III. Smaller (grade I) pterygia were only seen in patients belonging to plain areas.

On immunohistochemical examination, we found the mutant p53 positive cells in the epithelium of $72.5 \%$ of all the pterygium specimens, while all the normal conjunctiva specimens were p53 negative. Although, the incidence of abnormal p53 gene expression in pterygium was found to be marginally higher in the patients of high $(75 \%)$ versus low altitude $(70 \%)$, but the difference was not statistically significant ( $\mathrm{p}$-value $=1$ ). Quantitatively, the overall mean mutant $\mathrm{p} 53$ positivity for pterygium specimens was $31.03 \pm 18.19 \%$. The difference in the mean mutant $\mathrm{p} 53 \mathrm{immu}-$ noreactivity between the pterygia excised from the two groups was also found to be statistically insignificant ( $\mathrm{p}$-value $=0.53$ ).

The prevalence of p53 expression varies among tumour types, reportedly ranging from 0 to $60 \%$ in cancers of other organs viz., $56 \%$ in lung carcinoma, $50 \%$ in colonic carcinoma, $44 \%$ in skin tumours, etc. [52]. Besides, there are reports of abnormal p53 expression in approximately $7 \%$ of benign tumours, like benign phylloides tumour of the breast and benign breast biopsy specimens as well $[53,54]$. This study demonstrates abnormal p53 expression in pterygium cells too, as observed in the above mentioned benign tumours.

Such significantly high incidence of mutant $\mathrm{p} 53$ positivity $(72.5 \%)$ in pterygium specimens suggests a definitive role of p53 gene in pterygium pathogenesis. The results thus obtained support the theory that pterygium is a proliferative disorder rather than the historical notion of it being a degenerative condition. Our results are in concordance to some of the recent studies done with respect to p53 gene expression in pterygium. Abnormal p53 expression in ophthalmic pterygium tissue was first demonstrated by Tan $\mathrm{D}$ et al., who found that $3(37.5 \%)$ out of 8 pterygium specimens were positive for abnormal p53 expression on IHC 
Table 3. The p53 Gene Expression in Pterygium.

\begin{tabular}{|c|c|c|c|c|}
\hline IHC & Overall & $\begin{array}{c}\text { Group A } \\
\text { (High Altitude) }\end{array}$ & $\begin{array}{c}\text { Group B } \\
\text { (Low Altitude) }\end{array}$ & $\begin{array}{c}\text { Group C } \\
\text { (Control) }\end{array}$ \\
\hline p53 positive $(\%)$ & $29(72.5)$ & $15(75)$ & $14(70)$ & $0(0)$ \\
\hline p53 negative $(\%)$ & $11(27.5)$ & $5(25)$ & $6(30)$ & $10(100)$ \\
\hline p-value & 0.0001 & 0.0002 & 0.0003 & \\
$(\alpha=5 \%)$ & (significant) & (significant) & (significant) & \\
\hline Mean p53 positivity & 31.03 & 31.00 & 31.07 & \\
SD & 18.19 & 18.34 & 18.72 & \\
\hline
\end{tabular}

IHC stands for immunohistochemistry, done using DO-7 anti p53 antibody (which detects mutant p53 under non-denaturing conditions). Mean p53 positivity represents the mean of quantitative p53 positivity (in percentage) of pterygium specimens for the respective group. SD stands for standard deviation. Level of significance $(\alpha)$ was taken as $5 \%$ for this study. Two-tailed p-value was calculated using Fisher's exact test.

and concluded that pterygium is a growth disorder [29]. Tan D et al., in another study, concluded that pterygium development is a result of disruption of the normal process of apoptosis occurring in the conjunctiva, involving p53 gene mutation [32]. Ueda $\mathrm{Y}$ et al., performed IHC in pterygium specimens, for $\mathrm{p} 53, \mathrm{p} 21$ and proliferating cell nuclear antigen [34]. They found mutant $\mathrm{p} 53$ positivity in pterygia and suggested that the mutation in gene $\mathrm{p} 53$ was due to ultraviolet sunlight. They also proposed that mutant p53 positive pterygia can develop into limbal tumors. Weinstein O et al., demonstrated abnormal p53 gene expression in 7 (54\%) out of 13 pterygia on IHC staining and suggested that pterygium could be a result of uncontrolled cell proliferation rather than being a degenerative lesion [55].

Reisman D et al., found that in pterygium tissue the p53 gene undergoes mutation by monoallelic deletion [56]. Tsai Y et al., observed p53 gene mutations in pterygium epithelium and found no correlation between mutations and p53 protein levels as seen on IHC [57]. Pelit A et al., observed p53 immunoreactivity in pterygium specimens; suggested pterygium could be a result of uncontrolled cell proliferation and found no correlation between p53 immunoreactivity and ultraviolet irradiation [58]. Liang $\mathrm{K}$ et al., found high levels of p53 and other cell proliferation markers and low levels of apoptotic biomarkers in pterygium [59]. They proposed that both cell proliferation and apoptosis have an important role in pterygium pathogenesis. Ljubojević $\mathrm{V}$ et al., demonstrated p53 positivity in 15 (44\%) out of 34 pterygia examined by IHC [60]. They found no effect of age and gender on p53 expression, but did find an association between Ki-67 expression and $\mathrm{p} 53$ positivity. Like others, they too concluded that pterygium is a growth disorder rather than just a degenerative lesion.

In the current study, we observed much higher abnormal (mutant) p53 positivity $(72.5 \%)$ in pterygium specimens than that reported previously by Tan $\mathrm{D}$ et al., (37.5\%), Weinstein $\mathrm{O}$ et al., (54\%) and Ljubojević $\mathrm{V}$ et al., (44\%). The possible reasons for this may be the smaller sample size, different geographical or environmental factors, and the exclusion of high altitude population in these studies compared to the current study.

Several theories have been put forth with regards to pterygium development viz., autosomal inheritance, role of UV radiations, pterygium with dry eye, pterygium association with oxidative stress and molecular genetic alterations [7, 8, 14, 21-23]. The ad- vent of polymerase chain reaction (PCR) has enabled formulation of a few new theories of pterygium pathogenesis viz., the role of mutated limbal stem cells, growth factors and cytokines and viral (Human Papilloma Virus) involvement [61-64]. Although surgical excision of pterygium tissue with bare sclera technique or conjunctival flap autografting remains the primary mode of treatment in pterygium, recent molecular understanding of its pathogenesis has led to new therapeutic advances [65-70]. Use of antimetabolites like mitomycin C, beta irradiation and anti-vascular endothelial growth factors (anti-VEGF) like bevacizumab as adjuvant therapy have been reported to reduce recurrence rates post surgery [71-78].

Our study strongly suggests that molecular genetic alteration in the p53 gene has a significant role in pterygium pathogenesis. Since in this study, we found a high incidence $(72.5 \%)$ of mutant p53 positivity in pterygium epithelium, this might imply that it contains transformed cells and there is failure in the regulation and control of the cell cycle in pterygium cells. As we have observed the presence of mutant p53 immunoreactivity in pterygium, especially in the basal epithelial layers, the possibility of UV radiation induced mutation or transformation of pterygium cells cannot be ruled out. Several studies have suggested a positive correlation in this regard $[13,34,55]$. UV radiation is well known as a risk factor for various skin malignancies like squamous cell carcinoma, through its effect on the genetic material [13].

However, we found no significant altitudinal variation in the mutant p53 expression in pterygium in our study. We observed marginally higher pterygium p53 positivity in the higher altitude group compared to the lower altitude group, despite statistically significant difference in the mean altitudes and the mean annual UV indices of the two study groups. This might suggest that p53 mutations also possibly be caused by some other mechanisms besides the UV radiation induced damage. Similar findings were reported by Pelit A et al., [58]. Other possible cause(s) of p53 gene mutation in pterygium may be hereditary or viral presence $[7,23$, 79]. Further research investigating the possible mechanism(s) of p53 mutation in pterygium cells, other than the proposed UV mediated genetic alteration, is required.

It is well known that pterygium is a lesion with limited local invasion and inability to send metastases. However, its cells being mutant p53 positive, display genetic characteristics of a tumour, 
which might suggest pterygium to be a benign neoplastic tumour. Whether or not pterygium is pre-malignant, still remains a matter of debate. Most histological studies have ruled out pterygium premalignancy in the past, but a few recent studies have demonstrated histological features suggesting it to be premalignant [8082]. Although, classically regarded as a histologically benign lesion, the tumour like characteristics such as limited local invasion and an alarmingly high rate of abnormal p53 expression along with significant mean mutant p53 positivity in pterygium specimens certainly warrants further research in form of prospective randomised multicentric studies in this region, in order to clarify whether or not pterygium is premalignant.

\section{Acknowledgements \& Funding}

All of the research work was carried out at Shri Guru Ram Rai Institute of Medical \& Health Sciences, Dehradun. No financial support or funding was provided by any profitable institution or company for conducting this study. The authors neither had nor have any personal financial interest, whatsoever, in conducting or publication of this study.

\section{References}

[1]. Duke-Elder S, Leigh AG. Diseases of the outer eye part 1. In: Duke-Elder S, editor. System of ophthalmology. 1st Ed. Mosby, St. Louis, MO; 1958.

[2]. Solomon A, Pires RT, Tseng SC. Amniotic membrane transplantation after extensive removal of primary and recurrent pterygia. Ophthalmol. 2001;108(3):449-460.

[3]. Spraul CW, Grossniklaus HE. Tumors of the cornea and conjunctiva. Curr Opin Ophthalmol. 1996 Aug;7:28-34.

[4]. Hill JC, Maske R. Pathogenesis of pterygium. Eye. 1989;3( Pt 2):218-226.

[5]. Clear AS, Chirambo MC, Hutt MS. Solar keratosis, pterygium, and squamous cell carcinoma of the conjunctiva in Malawi. Br J Ophthalmol. 1979 Feb;63(2):102-109.

[6]. Coster D. Pterygium: an ophthalmic enigma. Br J Ophthalmol. 1995 Apr;79(4):304-305.

[7]. Hilgers J. Pterygium: its incidence, heredity and etiology. Am J Ophthalmol. 1960 Oct;50:635-644.

[8]. Coroneo MT. Pterygium as an early indicator of ultraviolet insolation: a hypothesis. Br J Ophthalmol. 1993 Nov;77(11):734-739.

[9]. Karukonda SR, Thompson HW, Beuerman RW, Lam DS, Wilson R, Chew $\mathrm{S}$, et al. Cell cycle kinetics in pterygium at three latitudes. Br J Ophthalmol. 1995 Apr;79(4):313-317.

[10]. Mackenzie FD, Hirst LW, Battistutta D, Green A. Risk analysis in the development of pterygia. Ophthalmol. 1992 Jul;99(7):1056-1061.

[11]. Moran DJ, Hollows FC. Pterygium and ultraviolet radiation: a positive correlation. Br J Ophthalmol. 1984 May;68(5):343-346.

[12]. Taylor HR. Ultraviolet radiation and the eye: an epidemiologic study. Trans Am Ophthalmol Soc. 1989;87:802-853.

[13]. Greenblatt MS, Bennett WP, Hollstein M, Harris CC. Mutation in the p53 tumor suppressor gene: clues to cancer etiology and molecular pathogenesis. Cancer Res. 1994 sep 15;54(18):4855-4878.

[14]. Di Girolamo N, Chui J, Coroneo MT, Wakefield D. Pathogenesis of pterygia: role of cytokines, growth factors, and matrix metalloproteinases. Prog Retin Eye Res. 2004 Mar;23(2):195-228.

[15]. McBride OW, Merry D, Givol D. The gene for human p53 cellular tumor antigen is located on chromosome 17 short arm (17p13). Proc Natl Acad Sci U S A. 1986;83(1):130-134.

[16]. Levine AJ, Finaly CA, Hinds PW. The p53 proto-oncogene and its product. In: Villareal LP, editor. Papilloma, SV40 and polyoma viruses. Common Mechanisms of Transformation by Small DNA Tumor Viruses. American Society for Microbiology. Washington, DC;1989.

[17]. Dippold WG, Jay G, DeLeo AB, Khoury G, Old LJ. p53 transformationrelated protein: Detection by monoclonal antibody in mouse and human cells. Proc Natl Acad Sci U S A. 1981 Mar;78(3):1695-1699.

[18]. Levine AJ (1993) The tumor suppressor genes. Ann Rev Biochem. 1993;62:623-651.

[19]. Cho Y, Gorina S, Jerey PD, Pavletich NP. Crystal structure of a p53 tumor suppressor-DNA complex: Understanding tumorigenic mutations. Science. 1994 July;265(5170):346-355.
[20]. Finley CA, Hinds PW, Levine AJ. The 553 proto-oncogene can act as a suppressor of transformation. Cell. 1989 Jun 30;57(7):1083-1093.

[21]. Spandidos DA, Sourvinos G, Kiaris H, Tsamparlakis J. Microsatellite instability and loss of heterozygosity in human pterygia. Br J Ophthalmol. 1997 Jun;81(6):493-496.

[22]. Detorakis ET, Sourvinos G, Tsamparlakis J, Spandidos DA. Evaluation of loss of heterozygosity and microsatellite instability in human pterygium: clinical correlations. Br J Ophthalmol. 1998 Nov;82(11):1324-1328.

[23]. Detorakis ET, Sourvinos G, Spandidos DA. Detection of herpes simplex virus and human papilloma virus in ophthalmic pterygium. Cornea. 2011 Mar;20(2):164-167.

[24]. Detorakis ET, Zafiropoulos A, Arvanitis DA, Spandidos DA. Detection of point mutations at codon 12 of Ki-ras in ophthalmic pterygium. Eye. 2005 Feb;19(2):210-214.

[25]. Kria L, Ohira A, Amemiya T. Growth factors in cultured pterygium fibroblasts: immunohistochemical and ELISA analysis. Graefes Arch Clin Exp Ophthalmol. 1998 Sep;236(9):702-708.

[26]. Marcovich AL, Morad Y, Sandbank J, Huszar M, Rosner M, Pollack A, et al. Angiogenesis in pterygium: morphometric and immunohistochemical study. Curr Eye Res. 2002 Jul;25(1):17-22.

[27]. Detorakis ET, Spandidos DA. Pathogenetic mechanisms and treatment options for ophthalmic pterygium: trends and perspectives (Review). Int J Mol Med. 2009 Apr;23(4):439-447.

[28]. Tan DTH. Pterygium. In: Holland EJ, Mannis MJ, editors. Ocular surface disease: medical and surgical management. (1st ed.), Springer-Verlag, New York; 2002.

[29]. Tan DT, Lim AS, Goh HS, Smith DR. Abnormal expression of the $\mathrm{p} 53$ tumor suppressor gene in the conjunctiva of patients with pterygium. Am J Ophthalmol. 1997 Mar;123(3):404-405.

[30]. Dushku N, Reid TW. P53 expression in altered limbal basal cells of pingueculae, pterygia, and limbal tumors. Curr Eye Res. 1997 Dec;16(12):11791192.

[31]. Sang AM, Lu H. Expression of p53 and flow cytometric analysis of DNA index and S-phase fraction in pterygium. Zhonghua Yi Xue Za Zhi. 2010 Jul 20;90(27):1890-1892.

[32]. Tan DT, Tang WY, Liu YP, Goh HS, Smith DR. Apoptosis and apoptosis related gene expression in normal conjunctiva and pterygium. Br J Ophthalmol. 2000 Feb;84(2):212-216.

[33]. Dushku N, Hatcher SL, Albert DM, Reid TW. p53 expression and relation to human papillomavirus infection in pingueculae, pterygia, and limbal tumors. Arch Ophthalmol. 1999 Dec;117(12):1593-1599.

[34]. Ueda Y, Kanazawa S, Kitaoka T, Dake Y, Ohira A, Ouertani AM, et al. Immunohistochemical study of p53, p21 and PCNA in pterygium. Acta Histochem. 2001 Apr;103(2):159-165.

[35]. Onur C, Orhan D, Orhan M, Dizbay Sak S, Tulunay O, Irkec M. Expression of p53 protein in pterygium. Eur J Ophthalmol. 1998 Sep;8(3):157-161.

[36]. Chowers I, Pe’er J, Zamir E, Livni N, Ilsar M, Frucht-Pery J. Proliferative activity and $\mathrm{p} 53$ expression in primary and recurrent pterygia. Ophthalmol. 2001 May; 108(5):985-988.

[37]. Lu P, Chen X, Kang Y, Ke L, Wei X,Zhang W. Pterygium in Tibetans: a population-based study in China. Clin Experiment Ophthalmol. 2007 Dec;35(9):828-833.

[38]. Alqahtani JM. The prevalence of pterygium in Alkhobar: A hospital-based study. J Family Community Med. 2013 Sep;20(3):159-161.

[39]. Li Z, Cui H. Prevalence and associated factors for pterygium in a rural adult population (the Southern Harbin Eye Study). Cornea. 2013;32(6): 806-809.

[40]. Lu J, Wang Z, Lu P, Chen X, Zhang W, Shi K, et al. Pterygium in an aged Mongolian population: a population-based study in China. Eye. 2009 Feb;23(2):421-427.

[41]. Nangia V, Jonas JB, Nair D, Saini N, Nangia P, Panda Jonas S. Prevalence and associated factors for pterygium in rural agrarian central India. The central India eye and medical study. PLoS One. 2013;8(12):e82439.

[42]. Singh MM, Murthy GV, Venkatraman R, Rao SP, Nayar S. A study of ocular morbidity among elderly population in a rural area of central India. Indian J Ophthalmol. 1997 Mar;45(1):61-65.

[43]. Marmamula S, Khanna RC, Rao GN. Population-based assessment of prevalence and risk factors for pterygium in the South Indian state of Andhra Pradesh: the Andhra Pradesh Eye Disease Study. Invest Ophthalmol Visc Sci. 2013 Aug 9;54(8):5359-5366.

[44]. Paralikar SJ, Paralikar JH. High-altitude medicine. Indian J Occup Environ Med. 2010 Apr;14(1):6-12.

[45]. Kanski JJ, Bowling B. Clinical ophthalmology a systematic approach. 7th ed. London: Butterworth-Heinemann Elsevier.

[46]. Wu KL, He MG, Xu JJ, Li SZ. (1999) The epidemiological characteristic of pterygium in middle-aged and the elderly in Doumen Country. J Clin Ophthalmol 7(1):17-18.

[47]. Liu H, Yang J, Zhong L. Prevalence survey on pterygium in two counties of 
Hainan Province. Chin J Ophthalmol. 2001 Jan;37(1):21-23.

[48]. McCarty CA, Fu CL, Taylor HR. Epidemiology of pterygium in Victoria, Australia. Br J Ophthalmol. 2000 Mar;84(3):289-292.

[49]. Panchapakesan J, Hourihan F, Mitchell P. Prevalence of pterygium and pinguecula: the Blue Mountains Eye Study. Aust N Z J Ophthalmol. 1998 May;26(suppl 1):S2-S5.

[50]. Wong TY, Foster PJ, Johnson GJ, Seah SK, Tan DT. The Prevalence and risk factors for pterygium in an adult Chinese population in Singapore: The Tanjong Pagar Survey. Am J Ophthalmol. 2001 Feb;131(2):176-183.

[51]. Cameron M. Geographic distribution of pterygia. Am J Ophthalmol. 1964; $57: 880-883$

[52]. Harris CC, Holistein M. Clinical implications of the p53 tumor-suppressor gene. New England J Med. 1993 Oct 28;329(18):1318-1328.

[53]. Younes M, Lebovitz RM, Bommer KE, Cagle PT, Morton D, Khan S, et al. p53 accumulation in benign breast biopsy specimens. Hum Pathol. 1995 Feb;26(2):155-158.

[54]. Kmet LM, Cook LS, Magliocco AM. A review of p53 expression and mutation in human benign, low malignant potential, and invasive epithelial ovarian tumors. Cancer. 2003 Jan;97(2):389-404.

[55]. Weinstein O, Rosenthal G, Zirkin H, Monos T, Lifshitz T, Argov S. Overexpression of p53 tumor suppressor gene in pterygia. Eye. 2002 Sep; 16(5):619-621.

[56]. Reisman D, McFadden JW, Lu G. Loss of heterozygosity and p53 expression in Pterygium. Cancer Lett. 2004 Mar 31;206(1):77-83.

[57]. Tsai YY, Chang KC, Lin CL, Lee H, Tsai FJ, et al. p53 Expression in pterygium by immunohistochemical analysis: a series report of 127 cases and review of the literature. Cornea. 2005 Jul;24(5):583-586.

[58]. Pelit A, Bal N, Akova YA, Demirhan B. p53 expression in pterygium in two climatic regions in Turkey. Indian J Ophthalmol. 2009 Jun;57(3):203-206.

[59]. Liang K, Jiang Z, Ding BQ, Cheng P, Huang DK, Tao LM. Expression of cell proliferation and apoptosis biomarkers in pterygia and normal conjunctiva. Mol Vis. 2011;17:1687-93.

[60]. Ljubojević V, Gajanin R, Amidžić L, Vujković Z. The expression and significance of $\mathrm{p} 53$ protein and Ki-67 protein in pterygium. Vojnosanit Pregl. 2016 Jan;73(1):16-20.

[61]. Kwok LS, Coroneo MT. A model for pterygium formation. Cornea. 1994 May;13(3):219-224.

[62]. Di Girolamo N, McCluskey P, Lloyd A, Coroneo MT, Wakefield D. Expression of MMPs and TIMPs in human pterygia and cultured pterygium pithelial cells. Invest Ophthalmol Vis Sci. 2000 Mar;41(3):671-679.

[63]. Gallagher MJ, Giannoudis A, Herrington CS, Hiscott P. Human papillomavirus in pterygium. Br J Ophthalmol. $2001 \mathrm{Jul} ; 85(7): 782-784$.

[64]. Piras F, Moore PS, Ugalde J, Perra MT, Scarpa A, Sirigu P. Detection of human papillomavirus DNA in pterygia from different geographical regions. Br J Ophthalmol. 2003 Jul;87(7):864-866.
[65]. Tomas T. Sliding flap of conjunctival limbus to prevent recurrence of pterygium. Refract Corneal Surg. 1992 Oct;8(5):394-395.

[66]. Anduze AL. Conjunctival flaps for pterygium surgery. Ann Ophthalmol. 2006;38(3):219-223.

[67]. Ang LP, Chua JL, Tan DT. Current concepts and techniques in pterygium treatment. Curr Opin Ophthalmol. 2007 Jul;18(4):308-313.

[68]. Basti S, Rao SK. Current status of limbal conjunctival autograft. Curr Opin Ophthalmol. 2000 Aug;11(4):224-232.

[69]. Memarzadeh F, Fahd AK, Shamie N, Chuck RS. Comparison of de-epithelialized amniotic membrane transplantation and conjunctival autograft after primary pterygium excision. Eye. 2008 Jan;22(1):107-112.

[70]. Das S, Ramamurthy B, Sangwan VS. Deep lamellar keratoplasty for recurrent advanced pterygium. Ophthalmic Surg Lasers Imaging. 2009 Feb;40(1):43-45.

[71]. Majmudar PA, Epstein RJ. Antimetabolites in ocular surface neoplasia. Curr Opin Ophthalmol. 1998 Aug;9(4):35-39.

[72]. Mattox C. Glaucoma filtration surgery and antimetabolites. Ophthalmic Surg Lasers. 1995 Oct;26(5):473-480.

[73]. Rosenthal JW. Beta-radiation therapy of pterygium. AMA Arch Ophthalmol. 1953 Jan;49(1):17-23.

[74]. Wilson B. Beta irradiation of pterygia. Trans Ophthalmol Soc Aust. 1963;23:96-100.

[75]. Kirwan JF, Constable PH, Murdoch IE, Khaw PT. Beta irradiation: new uses for an old treatment: a review. Eye. 2003 Mar;17(2):207-215.

[76]. Hosseini H, Nejabat M, Khalili MR. Bevacizumab (Avastin) as a potential novel adjunct in the management of pterygia. Med Hypotheses. 2007;69(4):925-927.

[77]. Bahar I, Kaiserman I, McAllum P, Rootman D, Slomovic A. Subconjunctival bevacizumab injection for corneal neovascularization in recurrent pterygium. Curr Eye Res. 33(1):23-28.

[78]. Emerson MV, Lauer AK. Emerging therapies for the treatment of neovascular age-related macular degeneration and diabetic macular edema. BioDrugs. 2007;21(4):245-257.

[79]. Detorakis ET, Drakonaki EE, Spandidos DA. Molecular genetic alterations and viral presence in ophthalmic pterygium. Int J Mol Med. 2000 Jul;6(1):35-41.

[80]. Vojniković B, Njirić S, Zamolo G, Toth I, Španjol J, Coklo M. Histopathology of the Pterygium in Population on Croatian Island Rab. Coll Antropol. 2007 Jan;31(Suppl 1):39-41.

[81]. Chui J, Coroneo MT, Tat LT, Crouch R, Wakefield D, Di Girolamo N. Ophthalmic Pterygium A Stem Cell Disorder with Premalignant Features. Am J Pathol. 2011 Feb;178(2):817-827.

[82]. Sun LL, Warrier S, Beckingsale P. Pterygium and Rate of Dysplasia in Surgical Specimens. J Clinic Experiment Ophthalmol. 2011 Jun 3;2:166. 